\title{
ABORDAGEM CLÍNICA DO PACIENTE COM FLUOROSE DENTAL
}

Carolinne GARCIA, Claudimara Laguna MARTINS, Bruno GUTIERRES, Cintia Gaio MURAD

Manchas brancas ocasionadas por fluorose podem afetar o convívio social de uma pessoa inibido-a de sorrir. Esses pacientes têm procurado tratamentos estéticos, devendo o profissional estar apto a oferecê-los com resultados satisfatórios. Uma alternativa para esta patologia é a associação dos tratamentos de microabrasão e clareamento dental. A microabrasão consiste no desgaste superficial do esmalte com pastas abrasivas. É uma alternativa conservadora com grande eficácia, e que associada ao clareamento dental tem melhorado os resultados estéticos. Este trabalho se propõe a apresentar um caso clínico que foi tratado com essa associação. O tratamento foi realizado com pasta de ácido fosfórico a 37\% associada à pedra-pomes e ácido clorídrico a $18 \%$ associado à pedra-pomes na face vestibular dos dentes, seguido de clareamento dental caseiro com peróxido de carbamida $16 \%$, materiais de fácil utilização pelos cirurgiões-dentistas e baixo custo. Foram realizadas duas sessões de microabrasão e clareamento durante quatro semanas. O resultado foi adequado, comprovando que a microabrasão associada a clareamento caseiro como tratamento estético em fluorose dentária, é um tratamento conservador, de baixo custo, com técnicas de aplicação relativamente fáceis, apresentando resultados satisfatórios para o paciente e o profissional.

Palavras-chave: fluorose dentária; microabrasão; clareamento. 